\title{
From openness to permeability: reframing open education in terms of positive liberty in the enactment of academic practices
}

Oliver, M. Learning, Media and Technology, 40(3):365-384. 03 Jul 2015.

DOI:10.1080/17439884.2015.1029940

\section{Abstract}

This paper explores the idea of open education, focusing specifically on the concept of openness. Previous discussions of open education are reviewed, using Knox's discussion of "unfreedoms" as a critical lens. Contrasts are then drawn with the concept of 'flexibility', to illustrate ways in which openness could be developed. This leads to consideration of ideas from sociomaterial theory, focusing on networks and boundaries.

A case study is then used to illustrate how these new developments play out empirically. The discussion then elaborates this in terms of ideas about mobility and fluidity. The paper concludes by arguing that the simplistic binary implied by 'openness' is largely irrelevant to the academic practices of teachers and learners. It is proposed that, instead, it should be replaced by a version that recognises the way individuals use infrastructures in pursuit of positive liberty. Such an alternative would help account for the various ways in which Universities are permeated by the personal, and vice versa.

\section{Introduction}

The concept of 'open education' has grown in importance and visibility, but the concept of openness is, arguably, under-developed within the field of learning technology. In this paper, the concept of open education will be reviewed; compared to wider discussions about flexibility in Higher Education; and illustrated using data from a study exploring contemporary academic practice.

\section{Closing education}

Although the concept and practice of 'open education' have grown in prominence over the last decade, debates continue to over-simplify ideas of openness in several important ways. For example, discussions tend to focus on relatively discrete problems such as accessing resources, but gloss over what people then do with these. These omissions mean that research has failed to open up educational practices, by ignoring the politics of technology production and use (Knox, 2013a).

However, the continued presence of such over-simplification may reflect its rhetorical value. As Selwyn notes (2012), research within Educational Technology frequently fails to connect with wider educational debates. Instead, it sustains itself through inward-focused arguments and citations, perpetuating an 'ed tech bubble' that exists in splendid isolation, developing the 'state of the art' without ever connecting to the 'state of the actual' (Selwyn \& Grant, 2009). In such a simplified circuit of discussion, it becomes possible to argue that Open 
Educational Resources (OERs) offer an obvious means of liberation from the problems that contemporary Higher Education is facing.

The dominant rhetorical move in such accounts, it has been argued, has been to deny the positive forms of liberty that an educational system is able to offer. Instead, advocates are "focusing their concerns on emancipation from hierarchies of control and the bypassing of systems which condition admittance to knowledge" (Knox, 2013b: 823). Knox argues that the emphasis in these accounts rests on shedding "unfreedoms", removing restrictions. Institutions such as Universities are therefore positioned as a bottleneck to the acquisition of knowledge; they are associated with exclusion and closure, and are presented as being self-interested. This has led commentators such as Downes to draw analogies between Universities and commercial corporations, in a way that reduces the question of freedoms to a simple binary.

The coming picture of learning, the one that we want to work toward, is open, where there is access for everybody, open in the sense of the internet, open in the sense that, if you can type in the URL, you can go to a web site. As compared to the closed spaces, such as AOL, or Prodigy, where you have to go, use their service, use their conditions and terms of service. (Downes, 2011: 36)

Although other authors tend to adopt a less black-and-white position, polarization remains common. Other authors have equated making content available online with "enabling universal education" (Caswell et al, 2008), have advocated breaking associations between quality and 'input' measures such as institutional infrastructures (Bradwell et al, 2013: 6), and proposed that Google can break "the monopoly (or at least hegemony)" that lecturers and University libraries once embodied (ibid: 16). The openness associated with online learning is widely purported to be a 'disruptive innovation', one that is able to cut through the "complex" and "confused" infrastructures that Universities have developed (Christiensen et al, 2011: 3) in order to overcome the geographic and financial barriers of access that current University structures represent.

Such positioning is evidently value laden: technologically mediated 'openness' is consistently associated with democratic, inclusive and radical ideals. Such idealism can be seen, for example, in Downes' argument (2011: 65) that even 'affordable' is an unacceptable qualification, because open resources should be free. Meanwhile other educational possibilities are positioned as conservative, exclusionary or controlling of learners or knowledge. From this perspective, even the Cape Town Open Education Declaration is "flawed because it betrays the process and spirit of the movement" (ibid, 100), since it addresses educational systems. The risk with such polarised accounts is that education is inevitably bad, because it is and can only ever be 'closed'. Arguably, whilst such a position may work as an ideology, it does not provide the nuance or discrimination that is needed analytically or practically to engage with education in a constructive way.

Moreover, this sense of fighting against closure does not necessarily help learners. Ironically, "as a result of this focus, there is a distinct lack of consideration for how learning might take place once these obstacles are overcome" (Knox, 2013b: 824; see e.g. Atkins et al, 2007: 4). Whilst some authors 
do consider social and cultural 'obstacles', including the ways in which communities might support self-directed learners (e.g. Albright's UNESCO OER Forum report, 2005), the role of teaching or systematic support as an important support or opportunity for learning is conspicuously absent (see, e.g., Downes, 2011: 88-91).

Moreover, learners are more commonly spoken for than carefully attended to. They are frequently enrolled in the rhetoric of open education as a group whose interests we should do more to serve. Careful empirical examination of what learners actually do is largely absent, however. There are some exceptions- for example, mentions of school students making transitions between classrooms and after school clubs (McAndrew et al, 2010) - but close analysis of the roles that spaces play in learning are rare in this context. Instead, as Knox notes, many of the arguments marshaled within these critiques hinge on economic models of education.

Some of these economic discussions concern education as a system. In such discussions, Higher Education is positioned as under threat, with technology as both the source of risk but also the promise of a new open, 'edgeless' or 'massively open' alternative to the established system (e.g. Bradwell, 2009; Weller, 2011; Watters, 2012). The openness associated with technology is both the problem and the solution, in these deterministic arguments.

However, even if the determinists are wrong and education as a system is not swept away, it may simply not be fit to face the challenges ahead. Laurillard (2008), for example, notes the estimated additional 125 million Higher Education places needed by 2020 , and observes that "when you measure student numbers in billions, staff-student ratios of 1:30 make no impact at all" (p320). She goes on to suggest that technology, and specifically "open teaching" (the idea of shared pedagogic patterns or learning designs, combined with content from OER repositories), may help to meet this challenge. However, as Slaton and Abbate (2001) point out, such technical approaches are also social and political: they create work for some and remove it from others, relocating expertise, and with it, power. Albright (2005), for example, suggests that reengineering educational systems at a national level to make greater use of open resources would be highly problematic. Such changes create clashes between the principles of open resources and contemporary market-based models of Higher Education. Scholars in low-income countries, it is argued, would need incentives to produce materials, and issue such as the high costs of staff time required to produce and maintain OERs remain unresolved.

Although others share economic concerns, their focus is wider, being concerned with the wider economic benefits of education to nation states. For example, in a report to the William and Flora Hewlett Foundation, Atkins et al stressed the value of "free access to high-quality content to be used by colleges and individuals in the United States and throughout the world to increase human capital" (Atkins et al, 2007: 2). Although such advocacy has much to say about how education ought to be, it does not engage with the detail of how education actually happens. Again, fundamental issues in practice are ignored and unresolved. 
Other economic arguments narrow their focus to institutions, and start to explore possible organisational reponses. For example, Barber et al (2013: 5) state bluntly that "the traditional university is being unbundled", and similarly, Anderson \& McGreal (2012: 380) argue "that some public and non profit institutions would be well advised to follow the lead of many other main stream service providers and create or partner together to develop and offer 'low cost or no frills services'”. They propose that this should be achieved by 'unbundling' the 'services' that a University engages in, such as content development, student support, library provision, etc, and by considering whether any student-tutor, student-student and student-content interaction can be reduced.

Similar arguments are put forward by Weller (2011), who draws analogies with developments in the newspaper and music industries in order to argue the threats to Universities in a 'digital economy' (Table 1).

\begin{tabular}{|l|l|l|l|}
\hline Function & $\begin{array}{l}\text { Higher } \\
\text { Education }\end{array}$ & Alternative & Resilience \\
\hline Content & $\begin{array}{l}\text { Lectures, } \\
\text { academic } \\
\text { journals }\end{array}$ & Open content, YouTube, Google & Weak \\
\hline Filter & $\begin{array}{l}\text { Lectures, reading } \\
\text { lists }\end{array}$ & Search, social network, Delicious & Weak \\
\hline Structure & $\begin{array}{l}\text { Courses, research } \\
\text { programmes }\end{array}$ & $\begin{array}{l}\text { Pathways, for example, Trailfire; } \\
\text { recommendations, for example, } \\
\text { Amazon }\end{array}$ & Medium \\
\hline Social & $\begin{array}{l}\text { Ready-made } \\
\text { student cohort }\end{array}$ & $\begin{array}{l}\text { Social network, communities, } \\
\text { wikis }\end{array}$ & Weak \\
\hline Support & $\begin{array}{l}\text { Tutorials } \\
\text { Rroups, peer to peer, expert } \\
\text { sourcing, for example, Mahalo }\end{array}$ & Medium \\
\hline Recognition & $\begin{array}{l}\text { Assessment and } \\
\text { accreditation }\end{array}$ & $\begin{array}{l}\text { Reputation, prior learning } \\
\text { recognition }\end{array}$ & Strong \\
\hline
\end{tabular}

Table 1: Weller's assessment of the relative resilience of disaggregated functions of Universities

Whilst Weller goes on to temper some of these claims in his subsequent discussion, it is interesting to note how the core of this argument once again consists of an either/or logic: either Universities or some radical alternative. None of these discussions engages seriously with the complexities of actual University work. Such discussions ignore the way in which Universities have existed in a precarious tension with other elements in society for well over a century (Taylor, 1999). They do not recognise that Universities already incorporate many 'alternatives' within their existing provision. Nor do such discussions acknowledge that removing the collectively-funded infrastructure of the institution means that individuals will have to put together equivalent acces from their own resources. (Nor are the analogies fully convincing, resting on anecdotal accounts of the industries described.) However, such discussions do at least move away from sweeping advocacy for change, and towards a more 
nuanced view, identifying specific variety of ways in which Higher Education might be 'opened'.

Part of the problem with these accounts is that they have avoided engaging with traditions of critique that can be traced back well over two decades. There are, for example, critiques of open education that question or resist the economic, industrialised logic associated with such forms of teaching and learning, in favour of social theories drawing on ideas of structuration and time-space (Evans \& Nation, 1992). They also ignore the longer history of open education, in which socio-technical developments play a complex role, whereby some aspects of education are opened up precisely as others are institutionalised (Peter \& Deimann, 2013). These wider traditions of critique will be considered next.

\section{Flexing education}

'Openness' is not the only metaphor that has been used to critique education. 'Flexibility', for example, has also been used to question the forms and practices of Higher Education, and has arguably generated better-developed insights. Barnett (2014), for example, invokes the example of the University of London which in 1858 "opened its degrees to any (male) student who could take them, irrespective of where in the world he studied" (p22); he further observes that flexibility as a concept has been a subject of research scrutiny for over two decades. The term has also been used (at least in Australia and the UK) to describe practices that might previously have been described as 'open' or 'distance' learning (Nicoll, 2006).

Although much critical scrutiny has taken place in relation to lifelong learning, there has also been a relatively nuanced discussion of how 'flexibility' is enacted in Higher Education. For example, Nikolova \& Collis' (1998) describe 19 different ways in which education might be considered flexible, including the topics, sequence and volume of content in a course; time and tempo of participation; the language and organization of learning; the places of study and support; and so on. This allows differentiation between different kinds of flexibility, and recognizes that courses may be more or less flexible relative to specific groups (who are assumed to have diverse requirements), rather than assuming that 'flexibility' is simply an inherent property of a course design.

A common thread across such discussions, however, is that 'flexibility' is normally understood to imply that teaching and learning can be liberated from the 'constraints' of time and place (Edwards \& Clarke, 2002) - a point echoed by Knox's later discussion of "unfreedoms" (2013b). As Edwards \& Clarke point out (2002: 157), moving education beyond 'closed' institutions is not an exclusively positive movement. Doing so extends control, just as it extends the range of knowing locations, by allowing education to extend the reach of discipline, normalisation and examination. Furthermore, moving 'out' of education does not always mean a move to a less circumscribed alternative: educational institutions are far from being the only space that carries boundaries. The labour market, for example, can just as easily be seen as "another container, into which students can be fed, and therefore engulfed or swallowed up" (Edwards \& Clarke, 2002: 162).

Fortunately, discussions of flexibility now recognise that there will inevitably be pay-offs between flexibility and other concerns, rather than merely assuming that 'more' is inevitably 'better'. For example, Barnett (2014: 19-20) discusses 
how flexibility around the time and pace of participation can impede collaborative pedagogies, that flexibilities designed to reduce course costs may have implications for student completion rates, and how greater choice within certain programme areas may draw resources from elsewhere leading to other areas of curriculum provision being withdrawn.

This is not to repudiate calls for flexibility; to the contrary. [...] But it is to point up the relational aspect of flexibility. As intimated, flexibility has its place amid a complex web of relationships and interests - across providers, students and stakeholders (including taxpayers). Accordingly, in introducing greater flexibility into the system - at any level, in any direction - work needs to be put in hand to examine likely implications for the legitimate interests of the manifold interest groups of a particular proposal and their interrelationships. (Barnett, 2014: 20)

Such considerations signal the ongoing relevance of another body of critique of flexible learning. Where relational aspects of flexibility, of the kinds referred to by Barnett or by Nikolova \& Collis above, systematically favour one group at the expense of another there may well be reasons to resist calls for greater flexibility. This may be the case, for example, where responsibility for students' failure to progress is shifted away from institutions and onto the individuals (Olssen, 2006). As authors such as Nicoll (2006) and Edwards (1997: 110; 1323) have argued, discourses of 'flexibility' can be understood as forming part of a wider neo-liberal project, one that positions learners as always bing in need of new training, new credentialing, in order to fill 'gaps' identified in their 'portfolio of learning' and make them more employable. Rather than a mechanism of liberation, it can become a 'corrosive' discourse, in which failure is blamed on individuals rather than inappropriate systems of education or employment, leaving people as 'prisoners of lifelong learning' (Crowther, 2004).

The flexible student is not a spontaneous occurrence. Students (including full-time students) have been engineered to become more 'flexible' as a result of policies, which have put more financial pressures on them to work in particular ways. It has also the created conditions under which the only way for many adults to access higher education is via 'flexible' modes of delivery. In this sense, students are forced to become 'flexible' and the flexibility to which they are supposed to conform is a particular pre-determined set of learning practices or process. (Clegg \& Steel, 2002)

Comparable discussions of the political risks of openness for students seem to be missing. Whilst research on open education has begun to differentiate forms of openness in ways that are analogous to work on flexibility, these relational or critical readings of 'openness' still appear to be under-developed, or even absent. In order to address this, it may be useful to build links between 'openness' and relational social theories.

\section{Networking education}

Cornford \& Pollock (2005) have noted the remarkable persistence of educational institutions, and observed that an important part of their value is that they enable "the co-location of learners, teachers, labs, class-rooms, lecture theatres, 
libraries and so on" (p170) in ways that enable learning to take place. They take seriously the possibility of alternative forms of educational support and engagement, but - in a move that echoes Knox's differentiation (2013b) between positive and negative liberties - challenge educators and researchers to consider what is lost as well as what is gained when such material resources are given up in the move to 'open' education.

The campus is best thought of not simply as a constraint but, to borrow Brown and Duguid's phrase, as a 'resourceful constraint' (Brown \& Duguid 2000: 246), one it would be premature to write off and which those developing distributed learning need to take seriously. (Cornford \& Pollock, 2005: 181, 170)

Their analysis takes up a sociomaterial perspective, one which draws attention to the necessary contribution of things and places as well as people in social achievements (Latour, 2005), and specifically to the way in which classrooms or community sites, textbooks, devices and people should not be "dismissed as simply a wash of material stuff and spaces. The things that assemble these contexts, and incidentally the actions and bodies including human ones that are part of these assemblages, are continuously acting upon each other to bring forth and distribute, as well as to obscure and deny, knowledge" (Fenwick et al, 2011: vii).

As Jones \& Healing (2010) have observed, networked perspectives reveal how "simple choices between online and face-to-face, or between distance and local, become increasingly complex as educational designs blend a variety of components in a variable geometry" (p320). In their study, which focused on students who were, formally, on conventionally 'closed' university courses, they found that the institutional infrastructure accounted for only part of learning. The default location for studying was within learners' place of residence, where they created their own work spaces (although lecture spaces, libraries and so on were also commonly used). In addition, learners interacted with each other using social networking sites, SMS text messaging or Voice Over Internet technologies as well as meeting face-to-face.

This network orientation emphasizes connections across and between groups and settings, and the way in which apparent boundaries are porous, being constantly bridged and traversed by boundary-crossing objects that act as links between elements of networks, rendering them 'leaky' (Jones et al, 2008). Whilst this particular work draws on social network analysis rather than actor-network theory or its sociomaterial successors, the point still holds: whilst assumed boundaries may suggest the 'closure' of groups, of practices and/or of institutions, a closer analysis reveals heterogeneous networks that spill out across and beyond these boundaries.

One potentially interesting sub-category of such elements are boundary objects things that are meaningful within multiple contexts, "plastic enough to adapt to the local needs and constraints of the several parties employing them, yet robust enough to maintain a common identity across sites. [...] The creation and management of boundary objects is a key process in developing and maintaining coherence across intersecting communities" (Bowker \& Star, 2000: 297). Given Wenger's assertion (1998) that everyone is simultaneously a member of multiple 
communities, it seems likely that boundary objects exist and form markers for points where the boundaries of Higher Education become permeable, intersecting and interacting with other communities and other practices.

These theoretical perspectives suggest that it is highly unlikely that any social institution can resist all forms of human and non-human boundary crossing. Consequently, it would be prudent to assume that all such boundaries are permeable by default. This means that, instead of trying to establish whether something is 'open' or not, the focus should then be on the instances of boundary-crossing that take place, and consequently the kinds of 'openness' that characterize a system or institution.

Gourlay's analysis of contemporary lecturing (2012) illustrates this well. She argues that "the lecture theatre as a space is often cited as the quintessential site of educational practice - and as such is often positioned by proponents of innovation as retrograde, hierarchical and highly controlled" (p200). However, in contrast to this view, contemporary lecturing involves selecting, interpreting and synthesizing from the mass of online and print resources available, creating digital slides that are both presented live but also made available online via Virtual Learning Environments (VLEs), being 'lecture captured' so that the experience can be broadcast and/or be replayed at other times and in other places, all whilst students download resources from the VLE, text via mobile phones, access social networking sites, tweet, record the lecture themselves, and so on - not to mention the ways in which the lecture may go on to be reworked and incorporated into the student's own texts and assignments in the future.

As a result, the lecture as a social event is also no longer primarily face-to-face, may also be permeated with information and interlocutors from a distance, and may itself 'leak' out of the walls of the lecture room via online comments from participants to those not present. (Gourlay, 2012: 203)

Such analysis emphasizes how the binaries between the material and virtual, and also in this case between 'openness' and 'closed-ness', are blurred in practice to the point of being unsustainable. An alternative focus is needed, one which draws attention to the ways in which boundaries around education and learning are both constructed and overcome - in other words, to their permeability.

\section{Permeable education}

These considerations will be illustrated using data from a year-long investigation of students' uses of digital technologies in Higher Education (Gourlay \& Oliver 2013). The case study was based in a primarily postgraduate institution, located in London.

This setting obviously situates the evidence in a very specific context - but that is precisely the point of the ethnographic orientation that underlies sociomaterial analyses. A fuller critique could be developed by relating such work to studies conducted in other cultures, socioeconomic systems, sectors, policy environments, and so on. For example, interesting comparisons can be drawn with work undertaken in South Africa by Czerniewicz et al (2009). However, for the purposes of illustrating the theoretical points made above, a single case study 
provides sufficient evidence to challenge the very general, homogeneous assertions associated with conventional 'open education' discourses.

The study as a whole involved a dozen volunteers drawn from four groups of students: Postgraduate Certificate in Education (PGCE) students, taught Masters students, taught Masters studied at a distance, and doctoral students. All students can be classified as 'mature', representing the professionally-oriented, postgraduate specialization of the institution. The study also involved four members of staff, whose responsibilities included teaching (online and through conventional classes), doctoral supervision, research and administration.

Participants drew maps and used iPod Touch devices to document their day-today academic practices over 6-12 months. This multimodal journaling produced drawings, photographs, videos and textual notes; participants assembled these, presented them to the interviewers and discussed them. The first interview focused on students' history of using technologies in education. This was followed by 2-3 further interviews, exploring their experiences of using technologies to support their studies, and finally the process of producing assessed written work.

The study received institutional ethical approval; participants were assured anonymity (pseudonyms chosen by the participants are used here), of the confidentiality of their data and of their right to withdraw.

From this data set, four cases have been selected for presentation here. The first is Yuki, a female Masters student classified as an international student. The second is Juan, a male student, and a UK resident - although his Masters studies involved overseas fieldwork. The third is Sally, a UK resident doctoral student. The fourth is Gertrude, a member of academic staff who was responsible for developing an online postgraduate programme.

Yuki provided an image, which she titled, "the bathroom is a good place to read" (Figure 1). 


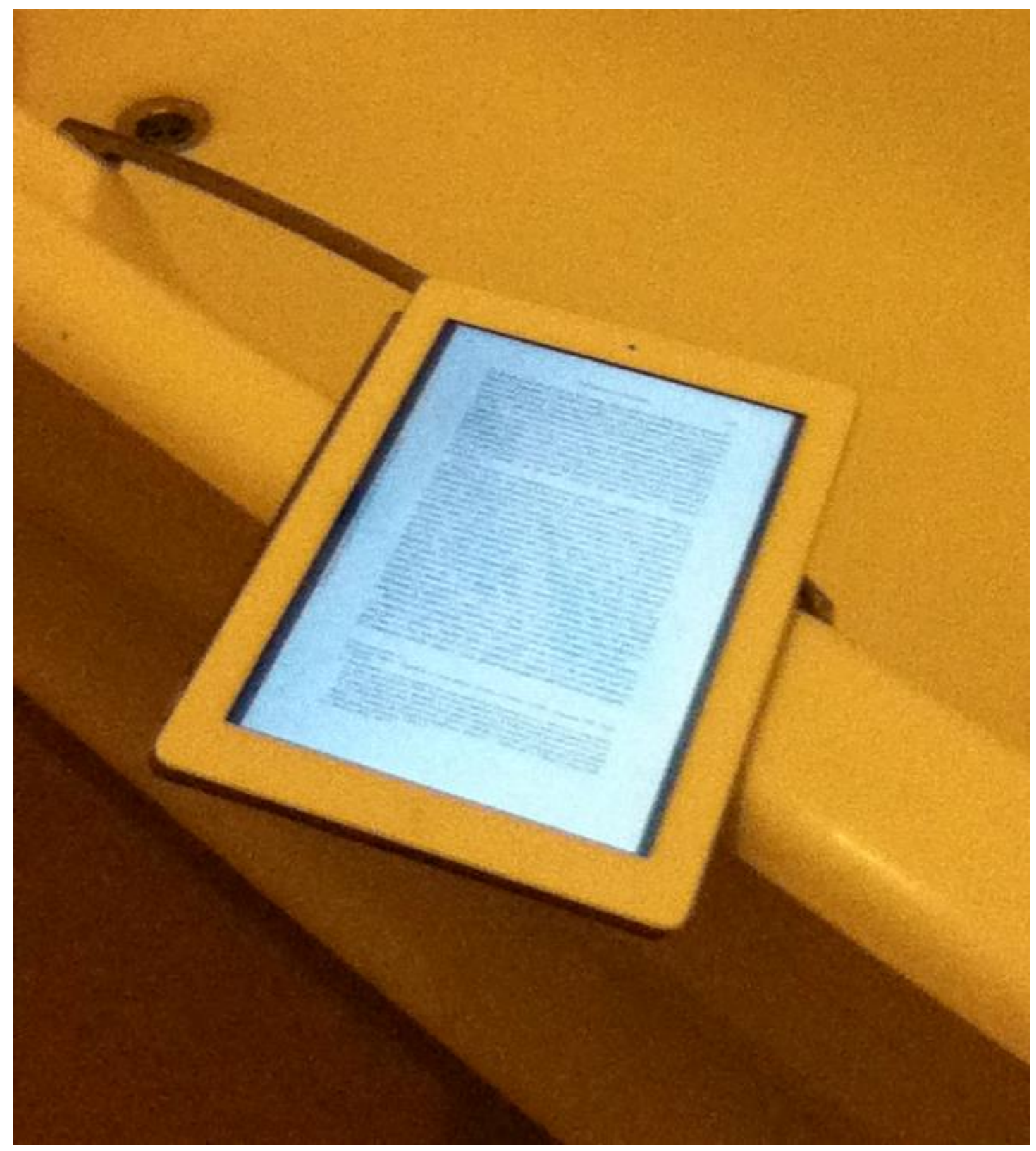

Figure 1: Yuki's photo

In the interview in which she explained this picture, Yuki described how she used the iPad to create and curate a range of resources relating to her course. She recorded lectures; digitised readings; accessed the course VLE; downloaded PowerPoint slides; emailed students and tutors, and so on. Things that would conventionally be associated with classrooms, libraries and other formal, 'closed' institutional spaces, were thus gathered together using the single device, and then brought into what might conventionally be seen as a very personal, private setting. Part of this process involved re-negotiating conventions - for example, she asked permission from lecturers to record their sessions, and digitized books she bought specifically for this purpose in order to reflect fair use under copyright law.

This line of connection from library and classroom to the bath was what enabled Yuki to study successfully. (The bath had important cultural connotations for her, which she could draw upon when studying.) Yuki's practices of digitization 
and curation enabled her to open up education so that she could engage with it on her own terms. Consequently, the bath became an important boundary crossing object, supporting conventional personal and private uses, but also educational study.

By contrast, Juan drew a map that emphasized the separation of home and University (Figure 2).

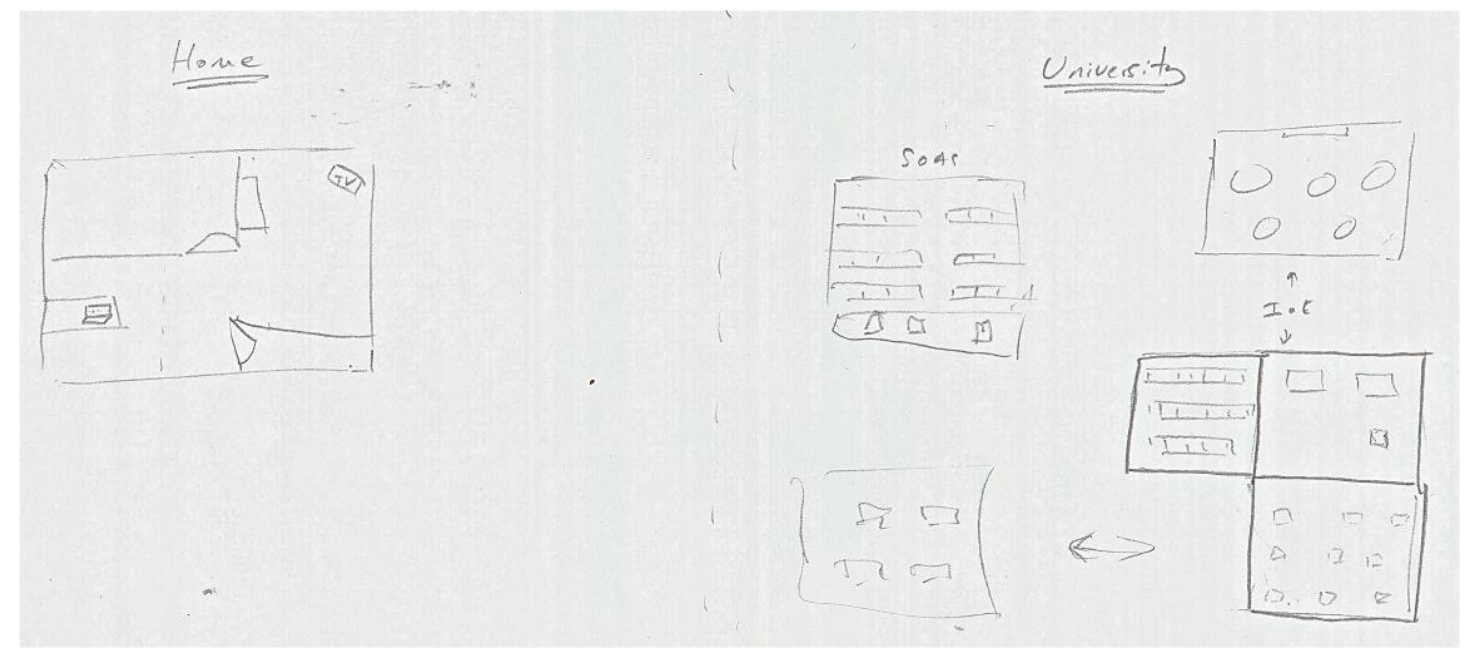

Figure 2: Juan's map of his study spaces

Juan felt that study was, if anything, too open; it 'leaked' into the rest of his life, in a way that he struggled to contain. Describing the map, he commented both on placing home and University at opposite extremes of the page, and also on his attempts to contain the incursion of study into his home to "a laptop here which is on the little table and that's kind of it. There is a sort of a line from which work doesn't, university work doesn't breach really." This was a personal choice: 'closing' the University involved active decisions and ongoing work to overcome a system he felt was already too 'open'.

Without too much work, I could do all of this there [at home], you know, but I choose not to because I like the change. And I like the movement maybe as well, so it is, yes, it's an important thing I suppose for there to be these sort of, these areas of not necessarily nothing, but of distinction, clear distinction between them.

For Juan, study also leaked beyond the 'host' University and into other educational institutions. He described, for example, how he chose to work primarily within the host University's library; however, because printing there was restricted to single-sided only, he went to a neighboring institution's library and used his girlfriend's username and password to print double-sided over their network, because this was cheaper. (In this case, arguably, his girlfriend's computational identity became a boundary crossing object, enabling two individuals to study as part of two separate institutional communities.) His use of texts, therefore, permeated two institutional boundaries, and then the printedoff texts would be read in several further locations, including whilst travelling on the bus.

Sally described 'leakage' that took place in the other direction, too. She drew attention to the way that boundary crossing objects such as web browsers, 
which were used for both personal activities and University work but collected data about the user on the same machine, threatened to conflate her personal and her University lives.

The only thing I struggle with [...] is the issue of like keeping your private life separate from your work life because I think increasingly the two, you're being forced to kind of mush the two together.

Because like [Another Institution] used to have its own email server and it would provide you with an email. Now it's provided by Gmail and it's like everybody knows that Gmail is the nosiest thing in the world and tracks absolutely everything you do. And [...] I'm a little bit uncomfortable with the idea that my work email knows what shopping I do and, you know what I mean? I just find the whole thing is starting to get a little bit scary.

Again, Sally did not have an issue with the institution being 'closed'; instead, for her, it was not closed off sufficiently to keep her personal life from leaking in.

Gertrude's practices, in some ways, seem to support conventional readings of institutional infrastructures as 'closed'. She drew a map (Figure 3) that showed her academic work as being distributed across various parts of her home; her travel; and her office. (As she was teaching online, she did not include conventional classrooms.)

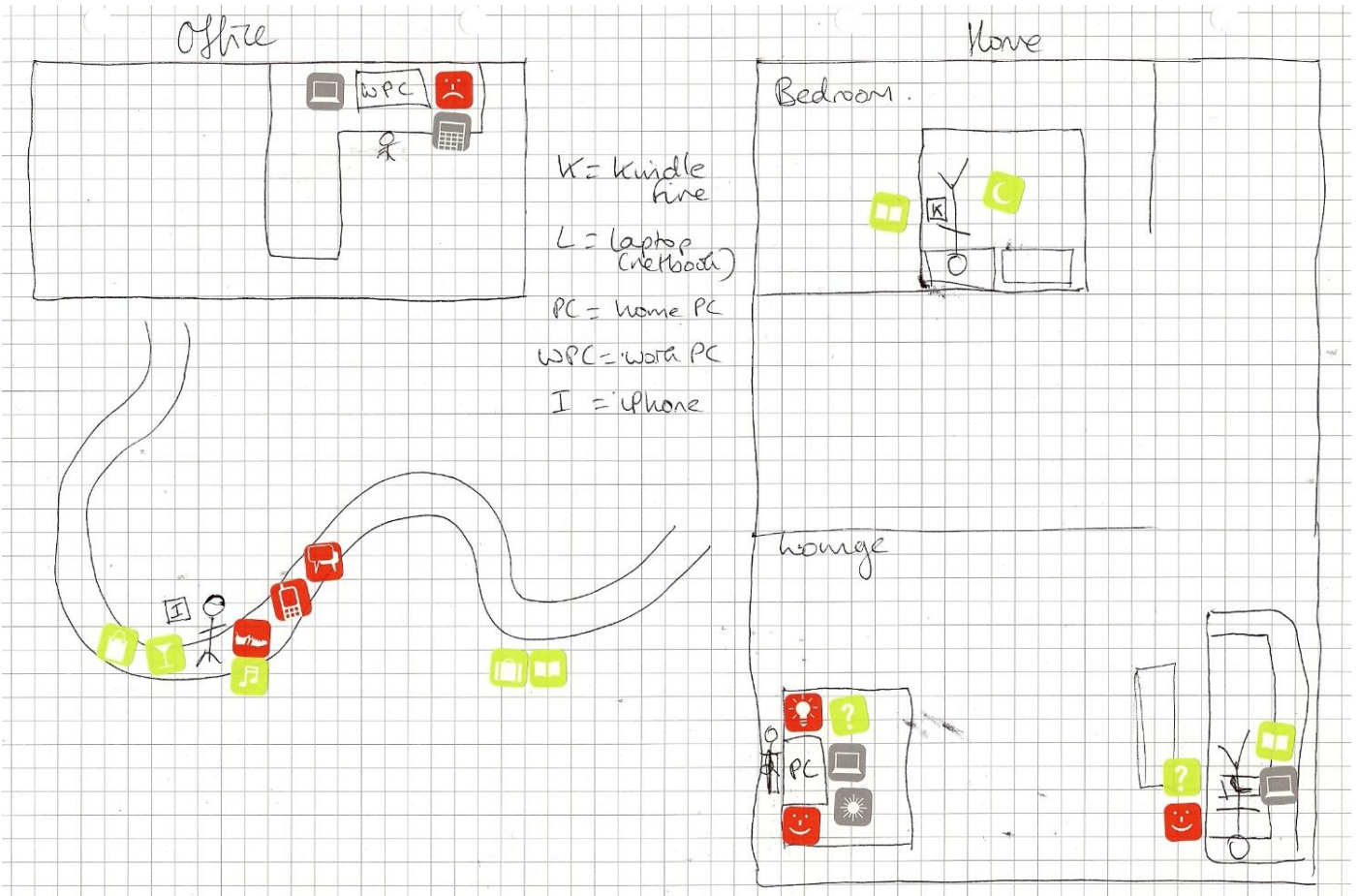

Figure 3: Gertrude's map of her academic work

She used stickers to denote the kinds of work and resources used in each setting, but also to denote how she felt about each space - her home spaces marked with "smiley" stickers, and her office with a sad face, because she found the process of producing her online course to be almost impossible using her institutional machine and services. These were rigidly controlled by a service she found unresponsive, leaving her unable to customise, adapt or extend their functionality. 
It just frustrates me because I don't have those problems anywhere else. I only have them in my office. And ironically the office is the one place where all of those kind of problems shouldn't be mine. You know, there's a whole service industry to support my use of technology in the office and yet it's the most challenging place for me to use technology. [...] It's that kind of thing that makes me think, well, there's just no... I'll just do it when I get home because it will just be so much easier.

Superficially, this experience echoes ideas of "unfreedom", and the removal of barriers to liberty. However, the situation was more complex - even when working at home, she still relied on institutional services such as the VLE, registry databases and library's digital collection to develop and deliver her online course; she had simply re-created her own private infrastructure at home to enable her to do this, using her own resources to support institutional work. In this sense, removing institutional "unfreedoms" was only the first part of the story - achieving positive liberties required the additional step of re-creating these on her own terms.

To enable her to work successfully in both settings, Gertrude transferred her work using an external hard drive.

I bought a hard drive which goes with me everywhere. And then what I've done with that is that I was worried about archiving and backing things up, so I've got it archived here and I've got it archived on our network drive at home and that has really facilitated me making sure that whether I'm here or here I've got access to all the documents that I need and the latest versions of them and they're all categorised, they're all organised in a way that suits me.

This is not a boundary-crossing artifact in the sense used by Bowker \& Star (2000), in that it remains within the practices of one community; however, it does cross from the 'boundary infrastructure' (Bowker \& Star, 2000: 313-4) of the material institution to the home, enabling connections between them. It also means that all of Gertrude's academic work became mobile, able to travel beyond the presumed 'closure' of the institution. Similar ends were achieved when working on train journeys using a combination of books, notebooks, an iPad, iPhone (connecting to institutional email), post-it notes and pens.

There was also considerable movement in the materials used to create her course. Whilst these were not designated as OERs, they were re-worked from a colleague's existing materials. Within Gertrude's account, there is no sense of scarcity, which is ostensibly the problem OERs are intended to address materials were experienced as being ready to hand, including a colleague's course, YouTube videos, library resources (a positive liberty, in that it was a guarantee of accessibility for all the learners on her course), resources from research projects and so on, as well as anything she writes herself. She described how she was constantly coming across resources and evaluating their potential value for her course.

As half of my brain is thinking about this I'm coming across other stuff and thinking, oh, that would be good for that, oh that would be, you 
know, and so, that's the other kind of thing that's just a little bit more incidental as it's going along.

Thus the effort needed was not finding resources - undercutting the 'access' arguments around OERs - but in tailoring them. It was contextualizing or reworking the resources that she had found that demanded her time and effort.

It's an important process for me to understand the module but it's also an important process for me to ensure that the module is fit for purpose for the differences of my students. Because my students are different.

So, while resources such as her colleague's course materials were not 'open' in the sense of OERs, they were 'open' to her. Technically, these resources belonged to the institution. As a consequence, they were both fettered by the 'unfreedoms' of Intellectual Property Rights, but also contributed to students' positive liberty because the institution could guarantee their availability as part of its infrastructure. Thus, whatever the formal categorization of the 'openness' of such resources, in practice, they were constantly being opened, reworked, reclosed, destroyed or released.

\section{Discussion}

Taken together, these four accounts shows academic work in motion. Such cases are necessarily illustrative, and no claims are made about how widely representative these individuals might be. Indeed, these are people who have engaged in Higher Education - they should not for example be understood as representing the experiences of people who feel excluded.

However, the complexity and distinctiveness of these cases demonstrates the point. Their experiences differ greatly, even within the same institution.

Consequently we cannot assume that the barriers they face or the solutions they may have developed will be similar, or that any single form of 'openness' will solve all of their problems. It is disingenuous to call for more openness on behalf of students, without first understanding the considerable variety of their experiences.

In these cases academic work was not 'trapped' inside a 'closed' institution or system. Instead, such work involved building bridges between classrooms and bathrooms, being enacted in private and public settings, leaking into and out of personal lives, and even simply moving between one institution and another. Some of these movements were challenging; several were arguably much more challenging than they actually need to be. Some of these movements extended the institution out beyond the boundaries of its material infrastructure and into personal spaces; others brought the personal (girlfriends or shopping preferences) into the institutional. The boundaries were therefore porous in many different ways: the institution was permeated by personal devices, relationship and meanings; and personal lives were permeated by institutional systems, tasks and resources.

There are clear connections between these movements and work drawing on sociomaterial perspectives to explore the concepts of spatiality and mobility (e.g. Edwards et al, 2011; Enriquez, 2011). Understanding how learning space are enacted and eventually become sedimented helps to explain why campuses have 
been so successful as 'resourceful constraints': as sites that are constantly revisited by academics and students, infrastructures are established that tether practices of learning to material resources such as books, teaching spaces and so on. These are the resources from which 'boundary infrastructure' forms (Bowker \& Star, 2000).

However, the same perspective also helps to explain how practices can be enacted across different spaces, tethering learning not to a site but to resources such as laptops (Brown \& Pallitt, 2014) - or in Yuki's case, to her iPad. Following such resources as they cross the infrastructures between institutional, personal and professional spaces of practice offers one way to trace permeability.

Arguably, such movements of resources are enabled by the variety of ways in which each can be taken up. In Law \& Mol's analysis of the success of bush pumps in Zimbabwe (2001), they move beyond a discussion of stable, 'immutable mobiles' to consider the variety of forms bush pumps take as parts break, are replaced, or are adapted, as it is taken up as part of different forms of social relations from village to village. In their analysis, the bush pump is a mutable mobile, a 'fluid object'.

Enriquez (2009) has made the point that educational technologies can be understood in the same way. A 'virtual learning environment' can be very different things from institution to institution, course to course, student to student, and week to week. Arguably it is also different when viewed on a desktop PC than when accessed via a mobile phone. In the data analysed here, some resources - such as Yuki's iPad - are materially similar in different contexts but functionally highly fluid, in one setting being a recording device, in another a means of curating digital resources, in another a means of reading. Juan's girlfriend is a code, a means of access to a library and a technical system, as well as a person. It might be tempting to assume that other resources show less fluidity - books, perhaps. However, Yuki's process of digitising readings in order to put them on her iPad involved microwaving books to melt the glue, passing the pages through a scanner and re-binding the pages. Without attention to practice, expectations about the relative fluidity or stability of objects remain unwarranted.

\section{Conclusions}

The idea of openness is important, contributing to fundamental discussions about the purpose of Higher Education, its relationship to society and its role in international development. However, arguably, debates around openness within Educational Technology have failed to engage with wider discourses, not least because they remain disconnected from the day-to-day realities of contemporary academic practice.

Re-framing 'openness' by drawing on relational, networked and sociomaterial theories offers a way to shift this debate. Such analyses indicate that social structures are inevitably permeable. Instead of an implied open/closed binary, the more important question then becomes, what kinds of permeability happn in these settings, and why?

These perspectives, emphasizing the importance of day-to-day practice, help ground the concept within what Selwyn \& Grant call the 'state of the actual' 
(2009). Empirical data about student and staff practices, examined through this lens, shows the irrelevance of simple binary assertions about whether Higher Education is 'open' or not. The lived experience of learners and teachers is complex, with devices, resources and services constantly crossing over from University to personal life and back again. Indeed, some learners are actively struggling to close off parts of their University experience in order to manage and contain it, because they already experience it as being too open. University study permeates learners' lives, just as their wider lives permeate their studies, in terms of their relationships, the material devices and resources they use, and the spaces in which they live and work. This suggests that contemporary discussions are focusing too strongly on "the idea of institutions choreographing their students in time-space", without recognising the point made long ago in the context of distance education that, "like all good dancers [...] students at a distance add their own interpretations and movements, and sometimes they demand of the choreographer that movements are changed" (Evans \& Nation, 1992: 9).

These experiences require us to rethink the constant push for openness. Specifically, they invite us to question in a critical manner whose benefits are best served by this systematic demand that we accelerate, rather than redress, the structural inequalities faced by students around the world in terms of their access to institutional infrastructures. We could create a form of equity by denying everyone access to institutions, but doing so would provide no guarantee everyone was equally well placed to cope with this situation, since some of are richer than others and so are better placed to re-create the kinds of infrastructures they need in order to pursue positive forms of liberty.

An alternative is to explore the ways in which Higher Education is already permeable - to people, resources, devices and so on - and to ask critical questions about peoples' experience of this. Where people experience barriers to participation, or where the movement of resources is blocked, these issues can then be attended to; but equally, so too can situations where people struggle to contain their educational experiences, and want to preserve boundaries between parts of their lives. Exploring how people study, how their study is interspersed amongst other activities, and what things (people, places, devices) consistently tether these practices will help us to understand how successful practices can be preserved, how people who struggle to succeed can be helped, and perhaps suggest new movements of people and resources that might be made possible.

The rhetoric of open education seeks to bring about a more equitable educational future. However, undermining existing structures provides no guarantee of future equity. Instead, the value of structures and resources need to be understood, so that any developments we might make remain connected to the experiences of the learners we claim to represent. Alongside the technical and legal possibilities of open education, we need to ask critical questions about the diversity of learners' experiences, and about what kinds of openness should be pursued in light of these. Just as learners have been forced to be 'flexible', we need to be clearer who stands to benefit from requiring students to be 'open', and where the responsibilities might lie for designing, enacting and resourcing these arrangements. 


\section{Acknowledgements}

I am particularly grateful to the anonymous reviewers for improvements to this draft, and particularly for encouragement to begin exploring the fluidity of technology in relation to permeability.

\section{References}

Albright, P. (2005) Open Educational Resources: Open Content for Higher Education (Final Forum Report). Paris: UNESCO. Available online:

http://www.unesco.org/iiep/virtualuniversity/media/forum/oer forum final $\mathrm{r}$ eport.pdf.

Anderson, T., \& McGreal, R. (2012) Disruptive Pedagogies and Technologies in Universities. Educational Technology \& Society, 15 (4), 380-389. http://www.ifets.info/journals/15_4/32.pdf

Atkins, D. E., J. S. Brown, \& A. L. Hammond. (2007) A Review of the Open Educational Resources (OER) Movement: Achievements, Challenges, and New Opportunities. Report to The William and Flora Hewlett Foundation, http://www.hewlett.org/uploads/files/ Hewlett_OER_report.pdf

Barber, M., Donnelly, K., Rizvi, S., \& Summers, L. (2013) An avalanche is coming. London: Institute for Public Policy Research. http://www. ippr. org/publication/55/10432/an-avalanche-iscoming-higher-education-and-therevolution-ahead.

Barnett, R. (2014) Conditions of Flexibility: Securing a more responsive higher education system. York: Higher Education Academy.

Bowker, G., \& Star, S. (2000) Sorting things out: Classification and its consequences. Cambridge, MA: MIT press.

Bradwell, P. (2009) The Edgeless University: why Higher Education must embrace technology. London: Demos.

Brown, C., \& Pallitt, N. (2014) "Laptops and Learning Spaces: Online, Offline and in between." In Proceedings of the 9th International Conference on Networked Learning. Edinburgh.

http://www.networkedlearningconference.org.uk/abstracts/pdf/pallitt.pdf.

Caswell, T., Henson, S., Jensen, M., \& Wiley, D. (2008). Open content and open educational resources: Enabling universal education. The International Review of Research in Open and Distance Learning, 9(1).

http://www.irrodl.org/index.php/irrodl/article/view/469/1009

Christensen, C. M., Horn, M. B., Caldera, L., \& Soares, L. (2011). Disrupting College: How Disruptive Innovation Can Deliver Quality and Affordability to Postsecondary Education. Innosight Institute.

http://files.eric.ed.gov/fulltext/ED535182.pdf

Clegg, S., \& Steel, J. (2002) Flexibility as myth? New technologies and postfordism in higher education. In Proceedings of the Networked Learning Conference, March, 2002, Universities of Lancaster and Sheffield. Available online:

http://www.networkedlearningconference.org.uk/past/nlc2002/proceedings/s ymp/08.htm. 
Cornford, J. \& Pollock, N. (2005) The University Campus as a 'resourceful constraint': [processand practice in the construction of the virtual university. In Lea, M. \& Nicoll, K. (Eds), Distributed Learning: Social and cultural approaches to practice, 170-181. London: RoutledgeFalmer.

Crowther, J. (2004). 'In and against'lifelong learning: Flexibility and the corrosion of character. International journal of lifelong education, 23 (2), 125-136.

Czerniewicz, L., Williams, K., \& Brown, C. (2009). Students make a plan: understanding student agency in constraining conditions. Research in Learning Technology, 17 (2), 75-88.

Downes, S. (2011) Free Learning: Essays on open educational resources and copyright. National Research Council Canada. Available online: http://www.downes.ca/files/books/FreeLearning.pdf.

Edwards, R. (1997) Changing places? flexibility, lifelong learning, and a learning society. Psychology Press.

Edwards, R., Tracy, F. \& Jordan, K. (2011) Mobilities, moorings and boundary marking in developing semantic technologies in educational practices. Research in Learning Technology, 19 (3) 219-232.

Enriquez, J. (2009) From Bush Pump to Blackboard: the fluid workings of a virtual environment. E-learning and Digital Media, 6 (4), 385-399.

Enriquez, J. (2011) Tug-o-where: situating mobilities of learning ( $\mathrm{t}$ )here. Learning, Media and Technology, 36 (1), 39-53.

Evans, T. \& Nation, D. (1992) Theorising open and distance education. Open Learning: The Journal of Open, Distance and e-Learning, 7 (2), 3-13.

Fenwick, T., Edwards, R. \& Sawchuk, P. (2011) Emerging Approaches to Educational Research: Tracing the Sociomaterial. London: Routledge.

Gourlay, L. (2012) Cyborg ontologies and the lecturer's voice: a posthuman reading of the 'face-to-face'. Learning, Media and technology, 37(2), 198-211.

Gourlay, L. \& Oliver, M. (2013) Beyond 'the social': digital literacies as sociomaterial practice, in Goodfellow, R. \& Lea, M. (eds), Literacy in the Digital University? Critical perspectives on learning, scholarship, and technology, 79-94. London: Routledge.

Jones, C. \& Healing, G. (2010) Networks and locations for student learning. Learning, Media and Technology, 35(4), 369-385.

Jones, C., Ferreday, D. \& Hodgson, V. (2008) Networked learning a relational approach: Weak and strong ties. Journal of Computer Assisted Learning, vol. 24(2), 90-102.

Knox, J. (2013a) The limitations of access alone: Moving towards open processes in education technology. Open Praxis, 5 (1), 21-29.

Knox, J. (2013b) Five critiques of the open educational resources movement. Teaching in Higher Education, 18 (8), 821-832.

Laurillard, D. (2008) Open teaching: The key to sustainable and effective open education. In T. Iiyoshi, \& M. S. Vijay Kumar (Eds.), Opening Up Education: The 
Collective Advancement of Education through Open Technology, Open Content, and Open Knowledge, 319-335. Cambridge, Mass: MIT Press.

Law, J. \& Mol, A. (2001) Situating Technoscience: an Inquiry into Spatialities. Society and Space, 19, 609-621.

McAndrew, P., Scanlon, E., \& Clow, D. (2010) An open future for higher education. Educause Quarterly, 33 (1). http://www.educause.edu/ero/article/open-futurehigher-education

Nicoll, K. (2006) Flexibility and lifelong learning: Policy, discourse, politics. London: Routledge.

Nikolova, I., \& Collis, B. (1998) Flexible learning and the design of instruction. British Journal of Educational Technology, 29(1), 59-72

Olssen, M. (2006). Understanding the mechanisms of neoliberal control: lifelong learning, flexibility and knowledge capitalism. International Journal of Lifelong Education, 25(3), 213-230.

Peter, S., \& Deimann, M. (2013) On the role of openness in education: A historical reconstruction. Open Praxis, 5 (1), 7-14.

http://openpraxis.org/index.php/OpenPraxis/article/view/23/8

Selwyn, N. (2012) Bursting out of the 'ed-tech' bubble. Learning, Media and Technology, 37 (4), 331-334.

Selwyn, N. \& Grant, L. (2009) Researching the realities of social software use: an introduction. Learning, Media and Technology, 34 (2), 79-86.

Slaton, A. \& Abbate, J. (2001) The hidden lives of standards: technical prescriptions and the transformation of work in America. In Allen, M. \& Hect, G. (eds), Technologies of Power, 95-143. Cambridge, MA: MIT Press.

Taylor, P. G. (1999) Making Sense of Academic Life: Academics, Universities and Change. London: Taylor and Francis.

Watters, A. (2012) Unbundling and Unmooring: Technology and the Higher Ed Tsunami. Educause Review, September/October, 60-61.

Weller, M. (2011). The digital scholar: How technology is transforming scholarly practice. London: Bloomsbury.

Wenger, E. (1998) Communities of practice: Learning, meaning, and identity. Cambridge, MA: Cambridge university press. 